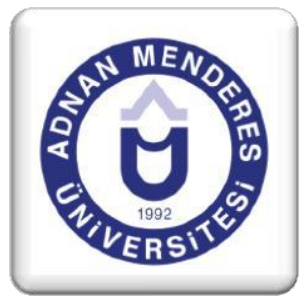

\title{
Cumhurbaşkanlığı Hükümet Sistemine \\ Geçişte 24 Haziran 2018 Seçimi Adaylarının Tweetlerinin Analizi
}

\author{
Mustafa Ali ÖZAY*
}

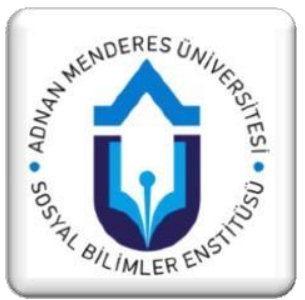

\section{ÖZET}

24 Haziran 2018 seçimleri Türkiye'nin yönetim sistemine yenilik getiren önemli bir dönüm noktasıdır. Yeni sistemle birlikte yürütmenin başı Cumhurbaşkanı olacak ve sistemin adı da Cumhurbaşkanlığı Hükümet Sistemi olacak. Bundan dolayı bu seçimde adayların ne yaptıkları, nelerin üzerinde daha çok durdukları seçmenler ve seçmenlerin kararları açısından önemlidir. Bu doğrultuda seçime katılmış olan adayların yapmış oldukları twitter paylaşımları bu araştırmada analiz edilmiştir. Sosyal medya olarak twitter'ın seçilmesinin nedeni ise burada yapılan paylaşımların kitlelere ulaşma süresinin daha hızlı ve kolay olduğunun düşünülmesidir. Adayların duygu ve düşüncelerine tercüman olan tweetler nitel veri analizine tabi tutulmuş ve sınıflandırılmıştır. 8 Ana Kod ve 13 Alt Kod ile yapılan bu sınıflandırma sonuçları bu çalışmada değerlendirilmiştir.

Anahtar Kelimeler: 24 Haziran 2018, Cumhurbaşkanlığı Hükümet Sistemi, Seçim, Nitel Analiz, Twitter

\section{Analysis of The Tweet of The Candidates from the 24 June Selection}

\begin{abstract}
June 24, 2018 elections is an important milestone in bringing innovation to Turkey's administrative system. The head of the executive with the new system will be the President and the name of the system will be the Presidential Government System. Therefore, in this election, what the candidates are doing is important in terms of voters and voters' decisions about what they are more concerned about. In this direction, the twitter shares of candidates who have participated in the election have been analyzed in this research. The reason for choosing twitter as social media is to think that the time it takes to reach the masses is faster and easier. Tweets that are interpreters of the candidates' feelings and thoughts have been subjected to qualitative data analysis and classified. The results of this classification with 8 Main Codes and 13 Sub Codes were evaluated in this study.
\end{abstract}

Keyword: June 24, 2018, Presidential Government System, Elections, Qualitative Analysis, Twitter

\footnotetext{
* Uludağ Üniversitesi SBE, Yönetim ve Organizasyon Bilim Dalı Tezli Yüksek Lisans Öğrencisi, mustafaaliozay@hotmail.com
} 


\section{GİRIŞ}

Sosyal medya kullanım popülizminin kullanıcılar arasında sürekli artmakta olduğu günümüz dünyasında insanlar artık sosyal medyanın gücünü de fark etmeye başlamışlardır. Sivil kullanıcıların haricinde sivil toplum kuruluşları, sendikalar, vakıflar, dini liderler, spor kulüpleri, siyasi parti liderleri hızla bu sürece adapte olmakta ve bu platformu en etkili şekilde kullanıp destekçilerini arttırmaya ve mevcut destekçilerine daha kolay ulaşmaya çalışmaktadırlar. Sosyal medyanın kitleleri etkileme oranı günümüzde yadsınamaz bir gerçeklikte hızla artmaktadır. Bir aktris oluşturmak istediği sosyal sorumluluk projelerini sosyal medya aracılığıyla yayıp çok hızlı bir şekilde sivil toplum kuruluşları ve insanları arkasına veya karşısına alabiliyor. Herhangi bir ülkenin siyasi liderinin söyledikleri ise ülkesini finansal krize sürükleyebiliyor. İnsanlar yapmış oldukları hukuksuz paylaşımlarla hukuki yaptırımlarla karşılaşabilirken, göstermiş oldukları duyarlılıklarla da toplum ve basın tarafından ödüllendirilebiliyorlar. Yani sosyal medya hayatın her alanına entegre olmuş, kanunlarla sınırları çizilmiş, insanların ve ülkelerin kaderini etkileyen ya da belirleyen bir mecra konumuna gelmiştir.

\section{Türkiye'de Sosyal Medya Kullanım Oranı}

Türkiye nüfusu toplam 80 milyon 810 bin kişidir. (https://www.nufusu.com-25/06/2018) Toplam nüfusun yaklaşık olarak yüzde 67'si olan 54 milyon 330 bin kişi internet kullanımına erişebiliyor. Aktif sosyal medya kullanıcısı ise 51 milyon, yani toplam nüfusun yaklaşık olarak yüzde 63'ü sosyal medya kullanıyor. Türkiye'de en çok kullanılan sosyal medya platformları, başta YouTube olmak üzere Facebook, Instagram ve Twitter'dan oluşmaktadır. Nüfusun yüzde 55'i olan 44 milyon 731 bin 500 kişi YouTube, yüzde 53'ü olan 41 milyon 478 bin 300 kişi Facebook, yüzde 46'sı olan 37 milyon 411 bin 800 kişi Instagram, yüzde 36's1 olan 29 milyon 278 bin 800 kişi ise Twitter kullanıyor. (www.sosyalmedyahaber.com-25/06/2018)

Türkiye'de insanlar:

- Günde ortalama 2 saat 48 dakikalarını sosyal medyada

- Günde ortalama 2 saat 44 dakikalarını ise televizyon başında geçiriyor. (www.dijilopedi.com-25/06/2018)

Ocak 2018 itibariyle We Are Social ve Hootsuide'ten alınan verilere göre sosyal medya paylaşım siteleri arasında twitter Türkiye'de en çok kullanılan 4. platformdur. Youtube, Facebook ve İnstagram'da doğrudan bir düşüncenin kitleler arasında paylaşımının zor olmasından dolayı bizde çalışmamızda Twitter'ı tercih etmekteyiz. (Resim 1.) 


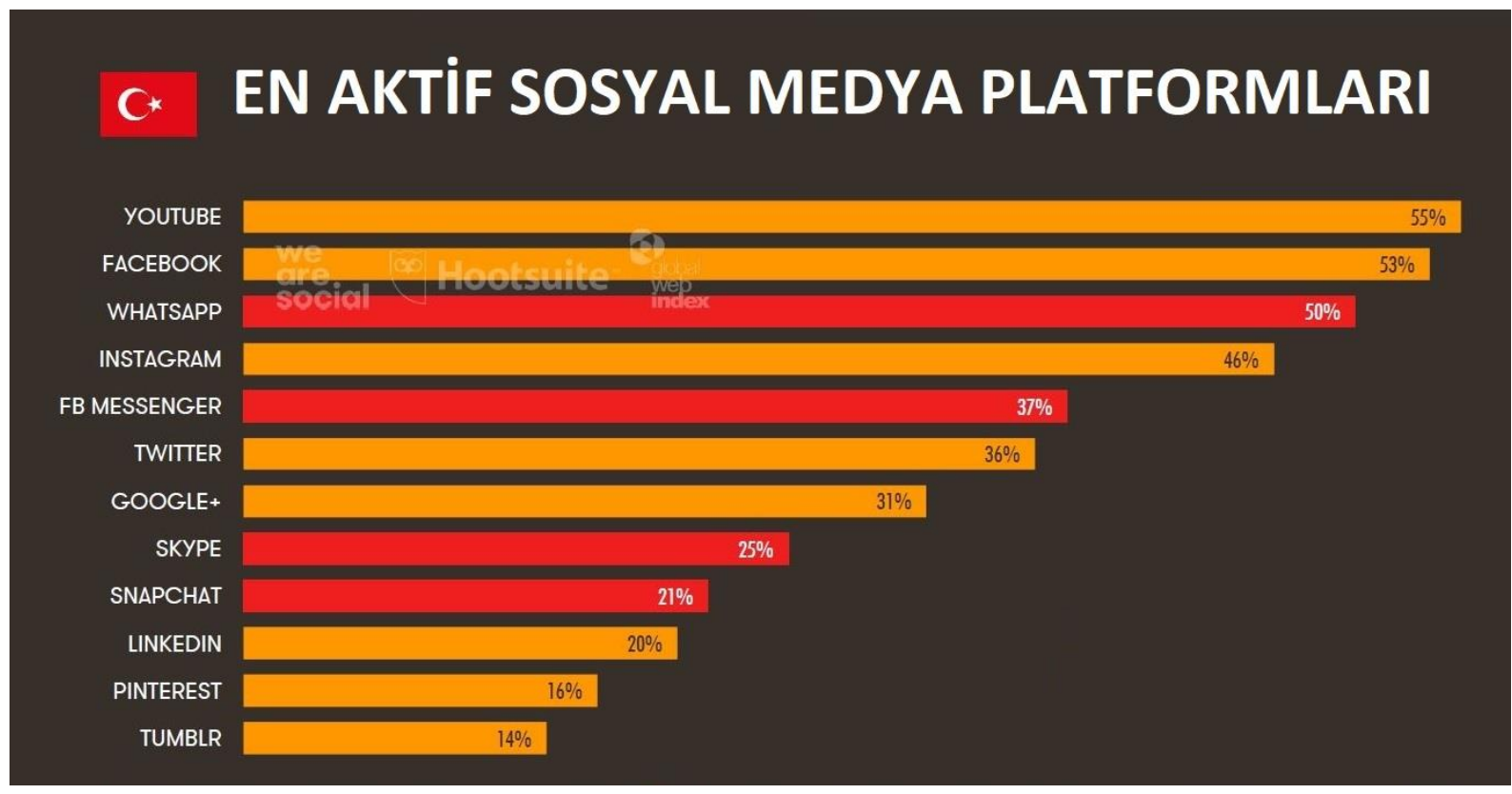

Kaynakça: https://wearesocial.com/ - 25.06.2018

\section{Seçimlerde Kitle İletişimi ve Sosyal Medya Kullanımı}

Yıllar boyunca politikacılar politik kampanyalarında avantaj elde etmek için farklı medya araçlarını kullanmayı denemişlerdir. Thomas Jefferson gazeteleri kullandı, Franklin D. Roosevelt radyonun gücünü tanıdı ve John F. Kennedy televizyonun politik potansiyelini anlayan ilk başkan oldu. Barack Obama sosyal medyanın gücünü keşfetti. 2008'deki Obama kampanyası, sosyal medyanın seçmenleri etkilemek ve onlara müdahale etmek için başarılı bir kampanya aracı olarak nası1 kullanılabileceğini göstermiştir. (Birgisdóttir, 2014:7)

Obama 2008 seçimlerinde sosyal medya sayesinde taraftarlarını hevesli savunuculara, bağışçılara ve gönüllülere dönüştürmeyi başardı (Aaker, Chang, 2009:1-19).

Malezya'da 2008 yılında yapılan seçimlerde Barisan Nasional hükümeti Demokratik Hareket birliği karşısında çok büyük bir kayıp yaşadı. Bu seçim sürecinde sosyal medyayı çok iyi yöneten Demokratik Hareket birliği Malezya'nın çoğu büyük şehrinde seçimleri önde tamamlayan parti oldu. Dönemin başbakanı Tun Abdullah'ta sosyal medyanın yıkıcı gücünü görmüş ve bunu kabul etmişti. (Fauziah Ahmad, et al. , 2012: 71-76; Mohd Azizuddin Mohd Sani, Knocks Tapowa Zengeni:2010).

Aragon'un (2013) 2011 İspanya ulusal seçimleriyle ilgili Barselona çalışması, siyasi adayların Twitter faaliyetleriyle seçim sırasında ki tartışmaları ve seçim günündeki önemli olayları yakından takip ettiğini ortaya koydu.

Siyasal iletişim, interneti güçlü bir iletişim aracı olarak kullanmakta ve siyasal aktörlerin internet ve sosyal medyada varlık göstermeleri hızla artan bir öneme sahip olmaktadır (Eray,2016: 112). Medya, siyasal örgütlerle vatandaş arasında haber, röportaj, yorum, inceleme ve araştırma türleri ile siyasal mesajları örgütlerden vatandaşa, vatandaştan gelen tepkileri ise yine bu tür yöntem ve tekniklerle siyasal örgütlere iletirler. (Aziz Aysel, 2003:8) 
Norveç'te 2013 yılında yapılan seçimler esnasında siyasi partilerin özel kanallara ve devlet kanallarına reklam vermesi ve seçim propagandası yapması yasaklandı. Bunun üzerine bazı partiler seçim çalışmalarını hızla sosyal medyaya taşıdılar ve reklam videolarını Youtube üzerinden taraftarlarına ulaştırdılar.(Bente Kalsnes, 2016:34)

Sokhan'ın (2014) 2013 yılındaki Kamboçya'da yapılan seçimlerle alakalı yapmış olduğu araştırmalar Kamboçya halkındaki sosyal medya kullanıcılarının büyük bir çoğunluğunun seçim sürecinde sosyal medyaya güvendiğini ve oy verme eğilimlerini sosyal medya paylaşımlarına göre şekillendirdiklerini ortaya koyuyor. Ayrıca, seçmenlerin destekledikleri kişilerin paylaşımlarını diğer insanlara aktarmak için en çok sosyal medyayı kullandıklarını ortaya koydu. (Sereyvisith Sokhan, 2014:12)

Muntean (2015) tarafindan Romanya'nın 2014 seçimlerinde sosyal medya kullanımının siyasi katılıma olan etkisini ölçmek amacıyla yapılan araştırmada özellikle genç seçmenlerin bundan en fazla etkilenen grup olduğu ortaya konulmuştur. Ayrıca araştırma sosyal medyanın siyaset arenasında ilk defa bu kadar büyük önem kazandığını da ortaya koymuştur. (Alina Muntean, 2015:82-83)

Aindrila Biswas v.d.(2014) tarafindan yapılan bir diğer araştırmada Hindistan'da ki durum ortaya konulmaktadır. Buna göre sosyal medyanın genç seçmenler üzerinde önemli bir etkiye sahip olduğu ortaya çıkmıştır. Siyasi partiler daha çok metropol ve gelişmiş şehirlerde insanlara sosyal medya aracilığıyla kolay bir şekilde ulaşabilmektedirler. Merkeze uzak taşrada ise seçmenlere ulaşmak için hala geleneksel metotlardan olan seçim broşürleri ve posterler kullanılmaktadır. Siyasi partiler sosyal iletişim araçlarının seçmenlere ulaşmada en hızlı ve en az maliyetli yol olduğunun farkındadırlar. Teknolojiden yararlanma bilgi kirliliklerini ortadan kaldırmak için ilk ağızdan hızlı bir cevap verebilmek için hayati bir önem taşımaktadır.

PenplusByte.org (2017) sitesince Gana'da ki 2016 seçimlerinde sosyal medyanın gücü ölçülmek istenmiştir. Buna göre seçim süresince parti liderlerinin paylaşımları ve bunlara yapılan geri dönüşler incelenmiştir. Bu seçimlerde önceki seçimlerde görülmeyen bir sosyal medya kullanımı olduğu fark edilmiştir. Seçmenler bu platformları çok yoğun bir şekilde kullanmıştır. Seçim süresince, ucuz bir propaganda aracı olması ve hızlı olması bakımından tüm adaylar tarafından tercih edilmiştir. Gana'da özellikle seçmenler tarafindan politik doğru bilgiye ulaşmak açısından Facebook, Twitter ve Youtube bolca tercih edilmiştir.

\section{Yöntem}

Bu çalışmada 24 Haziran 2018 seçiminde aday olan 6 ismin seçim süresince twitter aracılığıyla paylaşmış oldukları tweetlerin nitel bir çalışma ile içeriksel olarak analizi yapılmıştır. Erken seçimin yapılmasının belli olduğu 18 Nisan tarihi ile seçim çalışmalarının son günü olan 23 Haziran 2018 tarihleri arasında adaylar tarafindan atılan mesajlar twitter üzerinden alınmış ve veriler belge haline getirilmiştir.

Daha sonrasında bu belgeler MAXQDA 2018 programına yüklenmiştir. Programda oluşturulan kodlar aracılı̆̆ıyla adaylar tarafindan atılan tüm tweetler tek tek incelenerek çalışmanın şartlarına uygun olanların tamamı sınıflandırılmıştır.

Bu çalışma sonucunda Tablo 1'de gösterildiği üzere toplamda 2239 tweet incelenmiştir. Bu tweetler içerisinde kodlamaya uygun olan 1052 tweet bulunmuştur. Geriye kalan tweetlerden 1187 tweet ise araştırmaya dahil edilmemiştir. Bunun sebepleri ise paylaşlan tweetlerin 
herhangi bir sinıflandırma konusuna dahil edilememesi, farklı dillerde atılan tweetlerin olması, takipçilerin sorulara cevap niteliğindeki tweetler ve benzer içerikli tweetlerin olmasidir.

Tablo 1: Toplam İstatistiksel Sayılar

\begin{tabular}{|l|l|l|}
\hline $\begin{array}{l}\text { Cumhurbaşkanlı̆̆ı } \\
\text { Hükümet Sistemi Seçimi }\end{array}$ & $\begin{array}{l}\text { Seçim Süresince Paylaştı̆̆ı Toplam } \\
\text { Tweet Sayısı }\end{array}$ & Kodlamaya Uygun Tweet Sayısı \\
\hline $\begin{array}{l}\text { Doğu Perinçek } \\
\text { @Dogu_Perincek) }\end{array}$ & 164 & 122 \\
\hline $\begin{array}{l}\text { Meral Akşener } \\
\text { @meral_aksener) }\end{array}$ & 655 & 369 \\
\hline $\begin{array}{l}\text { Muharrem İnce } \\
\text { @vekilince) }\end{array}$ & 420 & 198 \\
\hline $\begin{array}{l}\text { Recep Tayyip Erdoğan } \\
\text { @RT_Erdogan) }\end{array}$ & 215 & 124 \\
\hline $\begin{array}{l}\text { Selahattin Demirtaş } \\
\text { @hdpdemirtas) }\end{array}$ & 491 & 120 \\
\hline $\begin{array}{l}\text { Temel Karamollaoğlu } \\
\text { (@T_Karamollaoglu) }\end{array}$ & 294 & 19 \\
\hline
\end{tabular}

Not: Adayların sıralaması alfabetik sıralamaya göre yapılmıştır.

\section{4. Çalışmanın Amacı, Metodolojisi, Önemi ve Literatüre Katkısı}

Araştırmada adayların sosyal medyayı daha çok hangi amaçla kullandıkları ve hangi konu hakkında ki fikirlerini daha fazla paylaştıkları ele alınmak istenmiştir. Adayların önem atfettiği öncelikli konular belirlenmiştir. Ayrıca gündemde en fazla yer işgal eden konular seçilerek adayların bu konu hakkında ki düşünceleri de tasnife dâhil edilmiştir.

$\mathrm{Bu}$ amaç doğrultusunda liderlerin yapmış oldukları paylaşımlar MAXQDA 2018 programı ile nitel bir analize tabi tutulmuştur. $\mathrm{Bu}$ analiz sırasında yapılan kodlamalar sayesinde tweetlerin içerikleri tasnif edilmiş̧ir. Bu doğrultuda oluşturulan kodlar Tablo 2'de gösterilmektedir. 
Tablo 2: Oluşturulan Kodlar (Ana Başılılar ve Alt Başlıklar)

\begin{tabular}{|c|c|c|c|c|c|c|}
\hline ANA & \multicolumn{6}{|c|}{ ALT BAŞLIKLAR } \\
\hline $\begin{array}{l}\text { A. Gündem } \\
\text { Değerlendirmesi }\end{array}$ & $\begin{array}{c}\text { Askeri } \\
\text { Harekatlar }\end{array}$ & \multicolumn{2}{|c|}{ Ekonomik Değerlendirmeler } & \multicolumn{2}{|c|}{ İşsizlik } & $\begin{array}{l}\text { İsrail-Filistin } \\
\text { Gerginliği }\end{array}$ \\
\hline \multicolumn{7}{|l|}{$\begin{array}{l}\text { B. Tamam- } \\
\text { Devam } \\
\text { Meselesi }\end{array}$} \\
\hline $\begin{array}{l}\text { C. Diğer } \\
\text { Adaylara } \\
\text { Yönelik } \\
\text { Eleştiriler }\end{array}$ & $\begin{array}{l}\text { Doğu } \\
\text { Perinçek'e } \\
\text { Yönelik }\end{array}$ & $\begin{array}{l}\text { Meral Akşener'e } \\
\text { Yönelik }\end{array}$ & $\begin{array}{l}\text { Muharrem } \\
\text { İnce'ye } \\
\text { Yönelik }\end{array}$ & $\begin{array}{l}\text { Recep } \\
\text { Tayyip } \\
\text { Erdoğan'a } \\
\text { Yönelik }\end{array}$ & $\begin{array}{l}\text { Selahattin } \\
\text { Demirtaş'a } \\
\text { Yönelik }\end{array}$ & $\begin{array}{l}\text { Temel } \\
\text { Karamollaoğlu'na } \\
\text { Yönelik }\end{array}$ \\
\hline \multicolumn{7}{|l|}{$\begin{array}{l}\text { D. Seçim } \\
\text { Güvenliği }\end{array}$} \\
\hline \multicolumn{7}{|l|}{$\begin{array}{l}\text { E. Seçim } \\
\text { Ziyaretleri }\end{array}$} \\
\hline \multicolumn{7}{|l|}{$\begin{array}{l}\text { F. Seçim } \\
\text { Vaatleri }\end{array}$} \\
\hline \multicolumn{7}{|l|}{$\begin{array}{l}\text { G. } 15 \text { Vekil } \\
\text { Olay1 }\end{array}$} \\
\hline $\begin{array}{l}\text { H. Kutlamalar } \\
\text { ve Yıldönümleri }\end{array}$ & & Kutlamalar & & Taziyeler & & Yıldönümleri \\
\hline
\end{tabular}

Tablodan da anlaşıldığı üzere toplamda 8 ana başlık (Kod) bulunmaktadır. Bu ana başlıkların bazıları ise alt başlıklara (Kod) ayrılmıştır. Bu alt başlıkların toplamı da 13 tanedir. Yani toplamda 21 tane başlık (Kod) belirlenmiştir. Alt başlıkları oluşturma eylemi yapılırken öne çıkan alt başlıklar tercih edilmiştir. Alt başlıkların çok fazla olması karışıklığa sebep olabileceğinin düşünülmesinden dolayı alt başlığa uygun olmayan tweet içerikleri ana başlığın içine atılmıştır. Kodlara göre tasnif işlemi gerçekleştirilmiştir. Paylaşımların içeriği, ilgili başlıklar (Kod) ile ilişkilendirilmiştir.

Böylece 24 Haziran 2018 başkanlık seçimlerinde başkanlık adaylarının hangi konularda daha fazla paylaşım yaptıkları ortaya konulmuştur. Çalışmanın içeriksel olarak sosyal medya paylaşımlarını analiz ediyor oluşu, yaptığı kodlamalar ve izlediği yöntembilim literatüre yapmış olduğu katkıdır.

\subsection{Kodların Açıklamaları}

Askeri harekâtlar ile ilgili yapılan paylaşımların temeli Türk Silahlı Kuvvetleri'nin 20 Ocak 2018 tarihinde başlatmış olduğu Zeytin Dalı Harekâtı ile Suriye'nin kuzeyinde bulunan Afrin bölgesinin terör oluşumlarından 2 aydan daha az bir sürede temizlenmesidir. Bir diğer harekât ise Irak'1n kuzeyinde bulunan Kandil bölgesinin teröristlerden temizlenmesi amaciyla Haziran 2018 tarihiyle Türk Askerinin bölgeye girmesidir. Bunlardan dolay1 adaylar bazı paylaşımlarında bu konulara değinmişlerdir.

İsrail-Filistin gerginliğiyle alakalı atılan tweetlerin sebebi ise ABD'nin İsrail büyükelçiliğini Tel Aviv'den Kudüs'e taşıma kararıyla birlikte Filistin ile İsrail arasında gerginliğin en üst 
düzeye çıkmasıdır. Bundan sonraki süreçte Filistin halkı uzun süre direniş yapmıştır. $\mathrm{Bu}$ olaylarda yüzlerce Filistin vatandaşı ölmüş, binlercesi yaralanmış ve hapse atılmıştır.

Tamam-Devam meselesinin altında yatan sebep ise Recep Tayyip Erdoğan'ın 8 Mayıs 2018 tarihinde ki grup toplantısında "Bir gün milletimiz tamam derse ancak biz o zaman kenara çekiliriz" demesinden sonra özellikle sosyal medyada bu konuyla alakalı birçok "Tamam" paylaşımlarının yapılmasıdır.

15 Vekil Olayında ise CHP'den 15 milletvekili partilerinden istifa edip IYİ Parti'ye geçmiştir. Burada ki amaç mecliste 5 vekili bulunan IYYİ Parti'nin 20 vekil elde edip kendi parti grubunu mecliste kurabilmesidir. Böylece 100 bin imzaya gerek kalmaksızın Meral Akşener'in adaylığının sağlanabilmesidir. Ancak daha sonrasında 15 vekil geriye dönmüş ve YSK tarafından toplanan imzalarda Meral Akşener yeterli imza sayısını toplamıştır.

Seçim ziyaretleri ile ilgili yapılan paylaşımların içine mitingler, e-mitingler, TV programları ve radyo kanalı ziyaretleri dâhil edilmiştir. Aynı il içerisindeki farklı ilçelerde yapılan mitingler ayrı ayrı olarak değerlendirmeye alınmışlardır.

Ekonomik Değerlendirmelerde ise Türk lirasının seçim öncesinde diğer dünya paraları ile birlikte ama onlara nazaran döviz karşısında daha fazla değer kaybetmesinden kaynaklanmaktadır. Seçim öncesinde dolar ve Euro gibi para birimleri Türk Lirası karşısında rekorlar kırarak yüksek değerler elde etmiş̧tir. Merkez bankasının faiz artırım kararları ve Ekonomi Bakanı Mehmet Şimşek ile Merkez Bankası Başkanı Mehmet Çetinkaya'nın Londra'ya yapmış olduğu ziyaretler Türk Lirasının bir nebze değer kazanmasını ve döviz karşısında ateşinin sönmesini sağlamıştır. 


\section{Bulgular}

Tablo 3. Kodların Oluşturulan Belgelerde Vurgulanma Sayıları

\begin{tabular}{|c|c|c|c|c|c|c|c|}
\hline KOD SİSTEMI & $\begin{array}{l}\text { Doğu } \\
\text { Perinçe } \\
\text { k }\end{array}$ & $\begin{array}{l}\text { Meral } \\
\text { Akşener }\end{array}$ & $\begin{array}{l}\text { Muharre } \\
\text { m İnce }\end{array}$ & $\begin{array}{l}\text { Recep } \\
\text { Tayyip } \\
\text { Erdoğan }\end{array}$ & $\begin{array}{l}\text { Selahattin } \\
\text { Demirtaş }\end{array}$ & $\begin{array}{l}\text { Temel } \\
\text { Karamollao } \\
\text { ğlu }\end{array}$ & $\begin{array}{l}\text { TOP } \\
\text { LAM }\end{array}$ \\
\hline $\begin{array}{l}\text { Askeri } \\
\text { Harekâtlar }\end{array}$ & 1 & & & 1 & & & 2 \\
\hline $\begin{array}{l}\text { Ekonomik } \\
\text { Değerlendirmele } \\
\mathbf{r}\end{array}$ & 5 & 12 & & 3 & 5 & 6 & 31 \\
\hline İşsizlik & & 1 & & & & & 1 \\
\hline $\begin{array}{l}\text { İsrail-Filistin } \\
\text { Gerginliği }\end{array}$ & 2 & 2 & 1 & 5 & 4 & 8 & 22 \\
\hline $\begin{array}{l}\text { Tamam-Devam } \\
\text { Meselesi }\end{array}$ & & 2 & 6 & & 1 & 6 & 15 \\
\hline $\begin{array}{l}\text { TK'ye Yönelik } \\
\text { Eleştiriler }\end{array}$ & 1 & & & & & & 1 \\
\hline $\begin{array}{l}\text { SD'ye Yönelik } \\
\text { Eleştiriler }\end{array}$ & 3 & & & & & & 3 \\
\hline $\begin{array}{l}\text { RTE'ye Yönelik } \\
\text { Eleştiriler }\end{array}$ & 2 & 13 & 7 & & 25 & 1 & 48 \\
\hline $\begin{array}{l}\text { MÍye Yönelik } \\
\text { Eleştiriler }\end{array}$ & 7 & & & & & & 7 \\
\hline $\begin{array}{l}\text { DP'ye Yönelik } \\
\text { Eleştiriler }\end{array}$ & & & & & 1 & & 1 \\
\hline $\begin{array}{l}\text { MA'ya Yönelik } \\
\text { Eleştiriler }\end{array}$ & 1 & & & & & & 1 \\
\hline Seçim Güvenliği & & & 3 & & 6 & 1 & 10 \\
\hline $\begin{array}{l}\text { Seçim } \\
\text { Ziyaretleri }\end{array}$ & 18 & 130 & 115 & 66 & 2 & 42 & 373 \\
\hline Seçim Vaatleri & 69 & 136 & 40 & 34 & 71 & 21 & 371 \\
\hline 15 Vekil Olayı & & 1 & & & & & 1 \\
\hline Yıldönümleri & 6 & 13 & 6 & 6 & & 10 & 41 \\
\hline Taziyeler & 2 & 27 & 4 & 1 & 1 & 11 & 46 \\
\hline Kutlamalar & 5 & 31 & 16 & 8 & 3 & 14 & 77 \\
\hline TOPLAM & 122 & 368 & 198 & 124 & 119 & 120 & 1,051 \\
\hline
\end{tabular}

Tablo 3'e göre Doğu Perinçek'in en çok seçim vaatleri (69) ile ilgili paylaşım yaptığı görülüyor. Arkasından önem verdiği diğer konular ise seçim ziyaretleri, kutlamalar ve yıldönümleri, diğer adaylara yönelik eleştiriler ( en çok Muharrem İnce) ve gündem 
değerlendirmeleri (8) gelmektedir. Doğu Perinçek işsizlik, 15 vekil olayı, tamam devam meselesi ve seçim güvenliği ile alakalı bir paylaşım yapma gereği duymamıştır.

Adaylar arasında en çok paylaşımı (655) yapan Meral Akşener daha çok seçim vaatlerine (136) önem vermiştir. Bu sayı toplam paylaşımlarının yaklaşık \%36'sını oluşturmaktadır. Yurdun hemen her bölgesinde miting yapan Meral Akşener'in en çok yaptığı ikinci paylaşım seçim ziyaretleriyle alakalıdır. Daha sonrasında sırayla kutlamalar ve yıldönümleri, Recep Tayyip Erdoğan'a yönelik eleştiriler(13), ekonomik değerlendirmeler konusunda paylaşımlar yapmıştır. Meral Akşener seçim güvenliği ve askeri harekâtlar konularında herhangi bir paylaşım yapmamıştır.

24 Haziran'da yapılan seçimlerin sonucuna göre en çok ikinci oyu alan Muharrem İnce ise twitterı daha çok seçim ziyareti duyurularını yapmak için kullanmıştır. Tweetlerinin sadece \%20lik kısmını vaatlerine ayırmıştır. Diğer adaylara yönelik eleştirilerinde en çok eleştiriyi Recep Tayyip Erdoğan almıştır. 15 vekil olayı, işsizlik, ekonomik değerlendirmeler, askeri harekâtlar gibi konularda ise bir paylaşımı bulunmamaktadır.

Seçimin kazanan ismi Recep Tayyip Erdoğan en çok seçim ziyaretlerini duyurmak için paylaşım yapmıştır. Paylaşımlarının \%27'lik bir kısmı seçim vaatlerinden oluşan Erdoğan aynı zamanda adaylar arasında en az paylaşım yapanıdır. Mitinglerinde Tamam-Devam meselesine en çok değinen Erdoğan bu konuyla alakalı hiçbir paylaşım yapmamıştır. Recep Tayyip Erdoğan seçim güvenliği, 15 vekil olayı ve diğer adaylara yönelik eleştiriler bakımından herhangi bir paylaşım yapmamıştır.

Seçim çalışmalarını Edirne'de bulunan cezaevinden sosyal medya aracılığı ile yürüten Selahattin Demirtaş ise en çok paylaşım yapan ikinci isimdir. Yaptığı paylaşımların yaklaşık \%59'unu seçim vaatleridir. Bu oran diğer adaylar arasında en yüksek oran olarak göze çarpmaktadır. Paylaşımlarının \%21'lik bölümünde ise Recep Tayyip Erdoğan'a yönelik eleştiriler yapmıştır. Önem verdiği üçüncü konu ise seçim güvenliği olmuştur ve bu konuda 6 paylaşım yapmıştır. 15 vekil olayı ve askeri harekâtlar konularında ise herhangi bir paylaşım yapmamıştır.

Değerlendirmemiz içerisinde ki son aday Temel Karamollaoğlu ise en çok seçim ziyaretlerini duyurmak için paylaşım yapmıştır. İkinci olarak ise seçim vaatleri konularında paylaşım yapmıştır ki bu diğer adaylar arasında ki en küçük (\%17) orandır. Temel Karamollaoğlu işsizlik, 15 vekil olayı ve askeri harekâtlar konularında bir paylaşım yapmamıştır.

Bütün adayların yapmış oldukları paylaşımların toplamının bir değerlendirmesi Tablo 4'te yapılmıştır. 
Tablo 4. Bütün Adayların Paylaşımlarının Kodlar Arasındaki Dağılımı

\begin{tabular}{|c|c|c|}
\hline KOD & Frekans & Yüzde \\
\hline Seçim Ziyaretleri & 373 & $35,5 \%$ \\
\hline Seçim Vaatleri & 371 & $35,3 \%$ \\
\hline $\begin{array}{l}\text { Kutlamalar ve Yıldönümleri } \\
\text { \Kutlamalar }\end{array}$ & 77 & $7,3 \%$ \\
\hline $\begin{array}{l}\text { Diğer Adaylara Yönelik Eleştiriler } \\
\text { \Recep Tayyip Erdoğan'a Yönelik }\end{array}$ & 48 & $4,6 \%$ \\
\hline $\begin{array}{l}\text { Kutlamalar ve Y1ldönümleri } \\
\text { \Taziyeler }\end{array}$ & 46 & $4,4 \%$ \\
\hline $\begin{array}{l}\text { Kutlamalar ve Yıldönümleri } \\
\text { IYıldönümleri }\end{array}$ & 41 & $3,9 \%$ \\
\hline $\begin{array}{l}\text { Gündem Değerlendirmesi } \\
\text { IEkonomik Değerlendirmeler }\end{array}$ & 31 & $2,9 \%$ \\
\hline $\begin{array}{l}\text { Gündem Değerlendirmesilİsrail- } \\
\text { Filistin Gerginliği }\end{array}$ & 22 & $2,1 \%$ \\
\hline Tamam-Devam Meselesi & 15 & $1,4 \%$ \\
\hline Seçim Güvenliği & 10 & $1,0 \%$ \\
\hline $\begin{array}{l}\text { Diğer Adaylara Yönelik Eleştiriler } \\
\text { IMuharrem İnce'ye Yönelik }\end{array}$ & 7 & $0,7 \%$ \\
\hline $\begin{array}{l}\text { Diğer Adaylara Yönelik Eleştiriler } \\
\text { ISelahattin Demirtaş'a Yönelik }\end{array}$ & 3 & $0,3 \%$ \\
\hline $\begin{array}{l}\text { Gündem Değerlendirmesi\Askeri } \\
\text { Harekâtlar }\end{array}$ & 2 & $0,2 \%$ \\
\hline $\begin{array}{l}\text { Diğer Adaylara Yönelik Eleştiriler } \\
\text { \Temel Karamollaoğlu'na Yönelik }\end{array}$ & 1 & $0,1 \%$ \\
\hline 15 Vekil Olayı & 1 & $0,1 \%$ \\
\hline Gündem Değerlendirmesil|̇ssizizlik & 1 & $0,1 \%$ \\
\hline $\begin{array}{l}\text { Diğer Adaylara Yönelik Eleştiriler } \\
\text { Doğu Perinçek'e Yönelik }\end{array}$ & 1 & $0,1 \%$ \\
\hline $\begin{array}{l}\text { Diğer Adaylara Yönelik Eleştiriler } \\
\text { IMeral Akşener'e Yönelik }\end{array}$ & 1 & $0,1 \%$ \\
\hline Kutlamalar ve Yıldönümleri & 1 & $0,1 \%$ \\
\hline Toplam(Geçerli) & 1052 & $0,1 \%$ \\
\hline Kayıр & 0 & $0 \%$ \\
\hline TOPLAM & 1052 & $100 \%$ \\
\hline
\end{tabular}


Buna göre adaylar en çok seçim ziyaretlerini duyurmak için bilgi vermişlerdir. Daha sonrasında en çok oranı alan ikinci paylaşım türü seçim vaatleri olmuştur. Adayların en önem verdikleri bir diğer konu ise kutlamalar ve yıldönümleridir. Şehitler, gaziler, doğal afet kazaları, ölümler, ölüm yıl dönümleri, olay yıldönümleri, milli ve dini bayramlar, özel gün ve geceler, şampiyonluklar, sporcu başarıları gibi konular adaylar tarafindan unutulmamış ve bu konuda paylaşımlar yapılmıştır.

Tüm bu değerlendirmelerin haricinde 2 tane Ana Kod-Alt Kod analizi yapılmıştır. $\mathrm{Bu}$ analizlerden ilki görsel 1'de gösterildiği üzere Gündem Değerlendirmelerinin dağılımı ile ilgilidir.

Görsel 1. Adayların Gündem Değerlendirmesi Paylaşımları

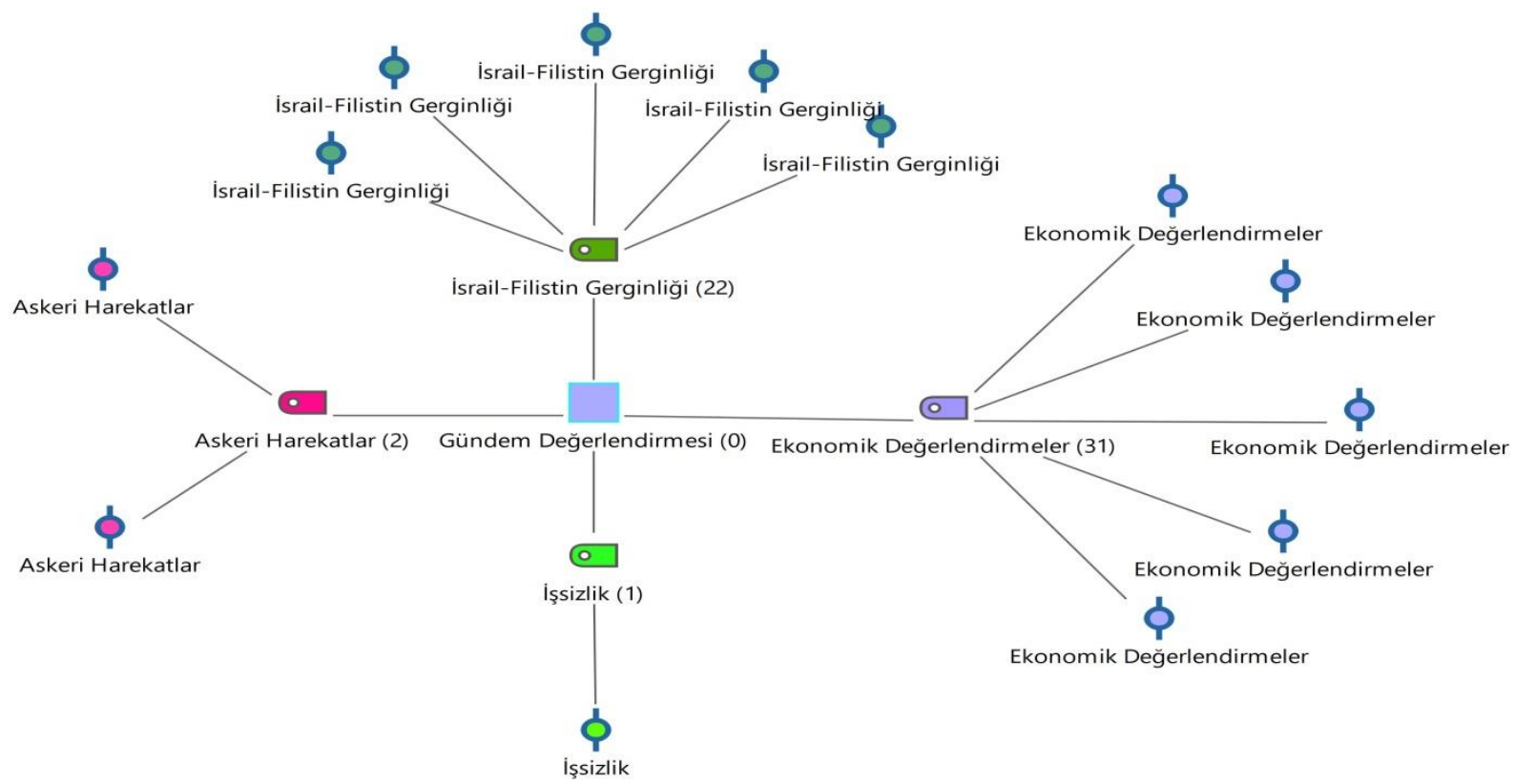

Görsel 1'e göre gündem değerlendirmelerinde adaylar en çok ekonomik değerlendirmeler yapmışlardır. 31 paylaşımın 12 tanesi Meral Akşener tarafından paylaşılmıştır. Bir diğer önem verilen konu ise İsrail-Filistin gerginliği olmuştur. Bu konuda en çok paylaşımı yapan ise Temel Karamollaoğlu'dur. Sırasıyla askeri harekâtlar hakkında 2, işsizlik hakkında ise 1 paylaşım yapılmıştır. İşsizlik hakkında atılan tek tweetin sahibi ise Meral Akşener'dir.

Bir diğer Üst Kod-Alt Kod analizi Diğer Adaylara Yönelik Eleştiriler kodu için yapılmıştır (Görsel 2). Adayların birbirlerine olan eleştirileri ile ilgili yapmış oldukları paylaşımlar bu kod içerisinde dağıtılmıştır. 


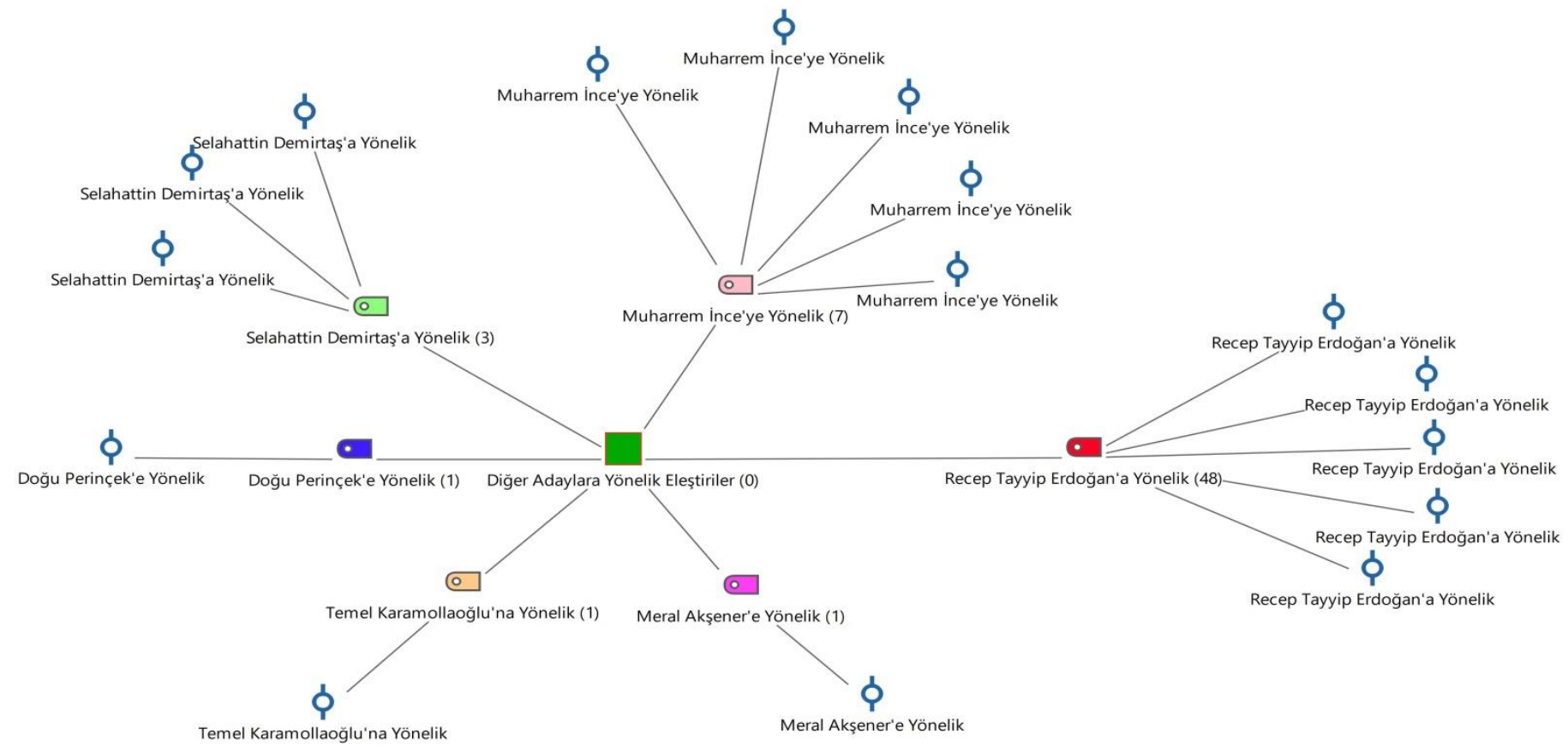

Görsel 2. Diğer Adaylara Yönelik Eleştirilerin Olduğu Paylaşımlar

Görsel 2'ye göre adaylar içerisinde en çok eleştiriyi alan aday Recep Tayyip Erdoğan'dır. Toplamda yapılan 61 eleştirinin 48'i Erdoğan için yapılmıştır. Daha sonrasında en çok eleştiri alan aday Muharrem İnce olmuştur. Üçüncü en çok eleştiri alan isimi ise Selahattin Demirtaş olmuştur. Diğer adaylar ise sadece 1'er eleştiri paylaşımı almışlardır.

\section{SONUÇ}

Dünya genelinde yapılan seçimlerde, referandumlarda sosyal medya araçlarının kullanımının sürekli arttığını görmekteyiz. Seçime katılan adayların en güçlü enstrümanlarından birisi olan sosyal medyanın gücü bütün adaylar tarafindan bilinmektedir. Adayların birbirlerine cevap verip soru yönelttiği bir platform tabi ki de birçok medya kuruluşu tarafından da ciddiye alınmakta ve haberleri yapılmaktadır. Duygu, düşünce ve fikirlerin ilk ağızdan en doğru şekilde yayılmasını sağlayan sosyal medyayı siyasi temsilcilerin günden güne daha fazla kullandığı aşikârdır.

Seçmenlere ulaşmayı hızlı, kolay, ucuz ve doğrudan sağlayan sosyal medya kolaylıkla kitleleri harekete geçirme imkânı da sağlamaktadır. Saniyeler içinde reaksiyon alınabilen bir mecrada kullanılan dil ve düşüncenin açıklığı da en üst seviyede olmalıdır. Yanlış kullanılan bir sözcük veya dikkatsiz yapılan bir paylaşım geri dönüşü olmayan sonuçlar doğurabileceği gibi adaylara seçimi kazandırabilir veya kaybettirebilir. Böyle önem verilen bir mecra kesinlikle alelacele kullanılmamalı sosyal medya uzmanlarına bu görev tevdi edilmelidir.

Altı adayın yarıştığı 24 Haziran 2018 seçimlerinde adayların yaptıkları paylaşımlar incelenmiştir. En çok önem verdikleri konular ayrıştırılmış ve sınıflandırılmıştır. 8 Ana Kod ve 13 Alt Kod ile yapılan bu sınıflandırmanın sonuçlarına bakıldığından adayların genel olarak siyasi düşünceleri ile paralel olarak söylemler içerisinde bulundukları söylemek yanlış olmayacaktır. 
Yapılan seçimin kısa bir özetini sunan bu çalışma gelecek yıllarda yapılacak olan seçim analizi çalışmalarına 1şık tutabilecek niteliktedir. Tüm bunlara ek olarak bu çalışmanın sağlayacağı bir diğer fayda, özelliği bakımından bir ilk olan 24 Haziran 2018 seçimlerinin gelecekte kolayca değerlendirilmesini açısından önem taşımasıdır. Seçim sürecinde yaşanan olayların kolayca hatırlanabilmesi açısından olaylar kısa açıklanmıştır. Böylece ileride yapılacak araştırmalarda araştırmacılara kolaylık sağlanması amaçlanmıştır. 


\section{KAYNAKÇA}

AAKER, J. ve CHANG, V. (2009). Obama and The Power of Social Media and Technology, Case Study, M-321, 1-40.

ARAGON, P., KAPPLER, K., KALTENBRUNNER, A., LANIADO, D. ve VOLKOVICH, Y. (2013). Communication dynamics in Twitter during political campaigns: The case of the 2011 Spanish national election, Policy \& Internet, 5(2), 183-206.

AZİZ, A. (2003). Siyasal İletişim, Nobel Yayınevi, Ankara.

BIRGISDOTTIR, L. (2014). The rising influence of social media in politics: How Barack Obama Used Social Media as a Successful Campaign Tool in the 2008 and 2012 Elections, Yüksek Lisans Tezi, University of Iceland.

BISWAS, Aindrila., INGLE, Nikhil. ve ROY, Mousumi. (2014). Influence of Social Media on Voting Behavior, Journal of Power, Politics \& Governance, 153-154.

ERAY, T. ve ASLAN A. (2016). Türkiye'de Siyasal Partilerin Web Sayfalarının Diyalojik İletişim Açısından İncelenmesi, İnönü Üniversitesi İletişim Fakültesi Elektronik Dergisi, 112-113.

FAUZIAH, A., CHANG, P., NORMAH, M., FARIDAH, I., WAN, A. ve WAN, M. (2012). Information Propagation and the Forces of Social Media in Malaysia, Asian Social Science, 8(5), 71-76.

Güncel Kullanıc1 Sayıları. (2018). http://www.sosyalmedyahaber.com/2018/03/2018guncel-sosyal-medya-kullanici-sayilari/ (Erişim Tarihi: 25 Haziran 2018).

KALSNES, Bente. (2016). The Power Of Likes: Social Media Logic and Political Communication, Doktora Tezi, University of Oslo.

MUNTEAN, Alina. (2015). The Impact of Social Media Use of Political Participation, Yüksek Lisans Tezi.

SANI, M. ve AZIZUDDIN, M. (2010). Democratisation in Malaysia: The Impact of Social Media in the 2008 General Election, 18th Biennial Conference of the Asian Studies Association of Australia in Adelaide, 1-16.

Social Media and Political Campaigning in Ghana. (2017). http://penplusbytes.org/publications/3552/ (Erişim Tarihi: 25 Haziran 2018)

SOKHAN, Sereyvisith (2014). Social Media and its Political impact: A Case Study of Cambodia 2013 Election, Proje Ödevi, 12-13.

Türkiye'de ki En Aktif Sosyal Medya Platformları. (2018). https://www.wearesocial.com/ (Erişim Tarihi: 25 Haziran 2018).

Türkiye'de Sosyal Medya Kullanım İstatistikleri. (2018). https://dijilopedi.com/2018turkiye-internet-kullanim-ve-sosyal-medya-istatistikleri/ (Erişim Tarihi: 25 Haziran 2018). 